\title{
Use of Agrowaste (Cassava Peels) to Cultivate Aspergillus niger for Biomass Production
}

\author{
Daniels Adetoyosi Olutosin ${ }^{1}$, Fadairo Johnson Kayode ${ }^{2}$ \\ ${ }^{1}$ Department of Biological Sciences, College of Natural and Applied Sciences, Achievers University, Owo, Nigeria \\ ${ }^{2}$ Department of Medical Laboratory Sciences, Faculty of Allied Health Sciences, University of Medical Sciences, Ondo, Nigeria
}

Email address:

toyosidanny@yahoo.com (D. A. Olutosin)

\section{To cite this article:}

Daniels Adetoyosi Olutosin, Fadairo Johnson Kayode. Use of Agrowaste (Cassava Peels) to Cultivate Aspergillus niger for Biomass Production. International Journal of Biochemistry, Biophysics \& Molecular Biology. Vol. 6, No. 1, 2021, pp. 11-17.

doi: 10.11648/j.ijbbmb.20210601.14

Received: November 23, 2020; Accepted: December 25, 2020; Published: April 16, 2021

\begin{abstract}
Clinical strain of Aspergillus niger was cultivated using un-supplemented cassava peels to produce fungal biomass in this work. The proximate contents and organoleptic properties (smell, taste, viscosity, colour) of both the fermented and unfermented cassava peels broths were investigated adopting known methods. The total biomass produced was also established through a period of nine days. The result obtained showed the moisture content of the broth reduced from $86.29 \%$ to $31.60 \%$ at the end of the experiment. Similarly, crude fibre reduced from $10.88 \%$ to $8.87 \%$. Also, the starch content reduced from $56.72 \%$ to $20.09 \%$ and cyanide reduced from $118.86 \mathrm{ppm}$ to $20.46 \mathrm{ppm}$. On the other hand, Protein content increased from $6.24 \%$ to $11.22 \%$ and Ash content also increased from $4.88 \%$ to $10.23 \%$. Biomass production increased daily from day one with initial weight of $1.253 \mathrm{gm}$ to $6.043 \mathrm{gm}$ on the $4^{\text {th }}$ day. The biomass production peaked at day 5 with a weight of $8.266 \mathrm{gm}$ and gradually reduced until a constant weight of $1.890 \mathrm{gm}$ was obtained on days 8 and 9 . The quantity of biomass produced within the period of study makes the medium; cassava peels a good materials for biomass production which can be used in some industries as raw materials.
\end{abstract}

Keywords: Agrowaste, Aspergillus niger, Biomass, Cassava Peels, Cyanide, Single Cell Protein

\section{Introduction}

A considerable quantity of by- products, wastes and cast offs are generated from the agro sector. These wastes if not properly disposed can accumulate in the environment and cause pollution [1]. The use of Agro-industrial based wastes in fermentation processes has been source of interest as a result of the low cost and ready availability. They are also environmentally friendly and are alternative sources of products like biogas, biofuel, mushroom, antibiotics, vitamins, antioxidant, animal feeds [2], as medium for fungal cultivation [3] and compost [4] amongst others. A large amount of national budget that could have been spent on social development are being used for fuel importation. This leads to poor infrastructural development. The generation of energy from biomass produced from agricultural waste will help reduce the dependence on fossil and can also negate the effect of social and environmental impacts such as unemployment and global warming [5]
The accumulation of wastes can lead to environmental pollution resulting in health crises as well as the distortion of normal soil microbiota, leading to poor quality produce [6]. [7] opined that the changing economic, social, political and cultural values of the world has prompted many countries to look inwards and exploring effective means of waste disposal using industrial biotechnology. The agro- industrial waste contains large amounts of nutrients which are essential for growth and proliferation of microorganisms and subsequently the synthesis of useful products like enzymes [8], energy production [9], biomass production [10] and organic acid like lactic acid, butanol, methanol and ethanol [11].

Agro- industrial waste utilization is on the upward rise and is expected to continue rise to be able to sustain the ever increasing population of the world. Most agricultural wastes have composition rich in sugars, minerals, proteins and phytochemicals and therefore, cannot be referred to as wastes, but rather as raw materials for other industrial processes. The nutrients and moisture content of these wastes provides 
conditions suitable for the growth and development of microorganisms. The ability of microorganisms to biodegrade agro products depends their enzymatic composition and this open up great possibilities for their use in fermentation processes. Microorganisms have unique properties required for bio- recycle that can drive environmental nuisance to zero waste. The use of agroindustrial wastes in fermentation processes is of interest due to their availability and low cost, they are also environmental friendly by reducing pollution and their ability to be recycled to make better secondary products [12]. Due to it's large availability and rich composition, agrowaste can be used in other processes. There is a great interest in the use of agricultural waste both from economic and environmental points of view. The economical aspect is based on the fact that such wastes may be used as low-cost raw materials for the production of other improved compounds, with the expectation of reducing the production costs while from the environmental point of view, reduces air pollution [13] and for generating energy including generating electricity, heating homes, fueling vehicles and providing process heat for industrial facilities [14].

Biomass is a renewable organic materials from plants and animals. Biomass energy is of great interest in both developing and developed countries because biomass alleviates dependence on limited fossil fuels, create employment opportunity and also develops the economy and revitalizes the rural communities. Biomass is a clean source of energy and reduces air emission than fossil fuels. Biomass energy is renewable and therefore sustainable [15]. The potential of microbes in alternative fuels and energy production is still largely unexploited. The need to explore single cell organisms in harvesting energy is a course that should vigorously pursued.

Biomass is a renewable organic materials from plants and animals. Biomass energy is of great interest in both developing and developed countries because biomass alleviates dependence on limited fossil fuels, create employment opportunity and also develops the economy and revitalizes the rural communities. Biomass is a clean source of energy and reduces air emission than fossil fuels. Biomass energy is renewable and therefore sustainable [16]. The potential of microbes in alternative fuels and energy production is still largely unexploited. The need to explore single cell organisms in harvesting energy is a course that should vigorously pursued.

Cassava (Manihot esculenta Crantz) is a staple African food that is widely consumed all over the world. But the waste produced thereof are been discarded and fed to animals in raw form with the high cyanide content. Large amount of the agro-industrial wastes are mainly composed by cellulose, hemicellulose and lignin, being called "lignocellulosic materials". Cassava wastes, peels, leaves and starch residues make up $25 \%$ of the total cassava plant [17]. The use of cassava peels is minimal due to the high content of cyanide and fiber as well as low protein and therefore is disposed off after cassava processing into food or other industrial products
$[18,19]$. The use of cassava peels as an energy producing raw materials is a means of limiting environmental degradation and energy paucity issues, as well as minimizing the health problems associated with environmental pollution as a result of the combustion of firewood and charcoal in cassava producing nations.

Microorganisms have been good candidates in agrowaste conversion and this has made them alternatives for high-input farming practices [20]. Aspergillus niger is useful in the industrial production of citric acid, gluconic acid and have been assessed as acceptable for daily intake by the World Health Organization [21]. A. niger fermentation is "generally recognized as safe" (GRAS) by the United States Food and Drug Administration under the Federal Food, Drug, and Cosmetic Act [22]. Other useful enzymes produced by A, niger include; Glucamylase, pectinase, Alpha galactosidase, glucose oxidases and cortisone.

Biomass produce by Aspergillus niger, is a byproduct of citric acid fermentation that has been a valuable material to many industries. Aspergillus niger degrades plant biomass polysaccharide to monomeric sugars, transports them into its cell and uses catabolic pathways to convert them to biochemical building blocks and energy [23].

Aspergillus niger is a ubiquitous filamentous ascomycete fungus, which efficiently degrades all plant polysaccharides through a wide range of extracellular carbohydrate acting enzymes (CAZymes). The Aspergillus group can, once cultivated, be used to synthesize useful industrial compounds such as 'glycoside hydrolases'. These enzymes are used in the process of converting biomass into biofuels - by breaking down cellulose and hemicellulose from plant cell walls, into a substance which is later converted into second-generation ethanol. This organism can also be used to produce bioactive metabolites, as well as other pharmaceutical products. In this work, the ability of $A$. niger to produce considerable biomass in cassava peels broth is investigated.

\section{Materials and Methods.}

\subsection{Collection and Preparation of Sample}

Cassava waste peels were collected from cassava mills in Owo metropolis. The peels were collected in clean polyethylene bags and taken into the laboratory for further analysis. The peels were washed thoroughly under running tap to remove sands, dirt and other unwanted materials. The cassava peels were then dried in the oven at $55^{\circ} \mathrm{C}$ for 14 days until crisp. The high temperature was to reduce the cyanide content. The dried peels were then pulverized into powder using the laboratory blender. The powder was sieved to remove fibres and particles.

\subsection{Collection and Maintenance of Aspergillus Niger}

Aspergillus niger spores were collected from slants in the microorganism bank of the Microbiology Laboratory of Achievers University, Owo. Ondo State. The spores were used to inoculate PDA slant and the slant allowed to incubate 
and kept until use.

\subsection{Inoculation of Cassava Peels Broth}

$0.5 \mathrm{grms}$ of the fungal spore was introduced into $10 \mathrm{mls}$ of PDA broth and allowed to incubate for 5 days at $28^{\circ} \mathrm{C}$. After this the A. niger culture was dispensed into $1000 \mathrm{ml}$ of cassava peels broth that was already prepared in a $2 \mathrm{ltr}$ volumetric flask. The flask was plugged with cotton wool and allowed to stand for fermentation to commence. Samples were taken daily for proximate analysis and biomass content.

\subsection{Proximate Analysis of Cassava Peels}

The Proximate analysis of the cassava peels was carried out to determine its nutritional compositions. Ash content was determined using the method of [24], crude fibre content was determined by the tricyclic acid TCA method (IITA) [25], moisture content was determined according to the oven method of AOAC [26], fat content was determined using the Soxhlet extraction, protein content was determined by the Micro-Kjeldahl method and carbohydrate content was given as total carbohydrate by difference.

\subsection{Total Cyanide Determination}

The cyanide contents of the fermented cassava peels were also determined using the method of (27). Total cyanide (cyanogenic glycosides +cyanohydrin $+\mathrm{HCN}$ ): In a stoppered $1.5 \mathrm{ml}$ tube $0.1 \mathrm{ml}$ extract and $0.05 \mathrm{ml}$ linamarase were added to $0.45 \mathrm{ml}$ phosphate buffer $\mathrm{pH}$ 7.0. After incubation at $37^{\circ} \mathrm{C}$ for $30 \mathrm{~min}$, the mixture was transferred to a $15 \mathrm{ml}$ tube containing $0.6 \mathrm{ml} 0.2 \mathrm{M} \mathrm{NaOH}$. After $5 \mathrm{~min}$, the sample was diluted with additional $2.8 \mathrm{ml}$ phosphate buffer (pH 6.0) and analyzed in the spectrophotometric procedure.

\subsection{Preparation and Sterilization of Medium}

$500 \mathrm{gm}$ of powdered cassava peels was measured into a $11 \mathrm{tr}$ volumetric and $750 \mathrm{ml}$ of water was added. The solution was boiled on the hot plate for about 15 minutes and the allowed to cool. The solution was then filtered and the filtrate collected was autoclaved at $121^{\circ} \mathrm{C}$ for 15 minutes. The sterilized medium was left overnight to cool. A loopful of Aspergillus niger on agar slant was used to inoculate the sterile medium and the medium stirred vigorously to allow for the dispersion of the spores of the fermenting organisms.

\subsection{Fermentation of Cassava Peels Broth by Aspergillus Niger}

Cassava peel broth prepared as described in 2.5, was inoculated with Aspergillus niger under sterile condition and was allowed to stand for 10 days under aerobic condition at a temperature of $30^{\circ} \mathrm{C}$. The $\mathrm{pH}$ were monitored daily until the completion of fermentation and the values recorded. The proximate analysis were carried out before and after fermentation and the values recorded.

\subsection{Physico-chemical Analysis}

The physic-chemical analysis like colour change, appearance, turbidity, smell were monitored prior to fermentation and daily for the duration of the fermentation and the values recorded.

\subsection{Determination of Biomass Content}

The biomass was determined at intervals of $24 \mathrm{hrs}$. The suspension was filtered daily and the broth filtered through Whatman No. 1 filter paper to harvest the mycelia. The filter cake paper was washed thrice with deionised water, dried at $105^{\circ} \mathrm{C}$ to a constant mass in an oven (Gallenkamp), and weighed as the biomass. The day a constant weight was achieved, the experiment was terminated.

\subsection{Statistical Analysis}

The values obtained in this work were subjected to statistical analysis using T- test.

\section{Results and Discussion}

The conversion of the agricultural waste to useful industrial raw material or energy yielding materials is of great importance especially in developing countries. Therefore most attention today must be given to possible use of microorganisms to convert relatively high-energy wastes into more useful and highly nutritious end product. However, there are some important considerations necessary for microbial conversion i.e. which microorganism or microorganisms possess potentials for the bioconversion of the organic materials under consideration

\subsection{Proximate Content of Cassava Peels}

The result of the proximate analysis of the fermented and unfermented is presented in Table 1. The moisture content was $86.29 \%$ at the start of experiment but reduced to $31.60 \%$ after the experiment. This is contrary to the work of [27] who observed an increase in moisture content of their medium which he attributed to the combined activities of the microorganisms present in the medium.

The ash content increased from $4.88 \%$ to $10.23 \%$. The increase in ash content could be suggestive of microbial activity. This agrees with the work of [28] who reported an increase in ash content in cassava products subjected to Saccharomyces cerevisae. The increase in ash content could also be attributed to the increase in mineral content, according to Oboh, [2006] increase in mineral content of a medium could be related to the loss of dry matter during microbial fermentation as microorganisms degrade carbohydrates and proteins. Protein content increased from $6.24 \%$ to $11.22 \%$ [29]. This increase could be attributed to the possible secretion of some extracellular enzymes (proteins) such as amylase, linamarase and cellulose [30]. Also, the increase in the growth and proliferation of the fungi used in medium to form of single cell protein may possibly 
account for the apparent increase in the protein content of the fermented peels $[31,32]$. It could also be attributed to the fermenting organism's attempt to make use of the cassava starch as a source of carbon [33]. Apart from this, the increase in the growth and proliferation of the fungi in the form of single cell proteins may possibly account for the apparent increase in the protein content of the fermented peels broth. This opinion is supported by the works of Akinfala and, Tewe [2004]; Tweyongyere, and Katongle, [200] s [34, 35].

The fat content increased from $1.39 \%$ to $2.91 \%$. The increase in the fat content might due to the increase in the microbial mass, activities of lipolytic microorganisms to secrete extracellular enzyme (lipase), secretion of microbial oil into the fermenting medium and other products from the metabolism [36]

Crude fibre of the unfermented broth reduced from $10.88 \%$ to $8.87 \%$ in the fermented broth. The decrease observed could be attributed to the ability of the Aspergillus niger to degrade the crude fibre in the fermenting cassava peel, secrete hydrolyzing and oxidizing enzymes involved in the conversion of recalcitrant compounds in the waste into utilizable compounds (35) and abundant production of organic acids resulting from fermentative dissimulation of carbohydrates [37].

The significant decrease $(\mathrm{P}<0.05)$ in the carbohydrate content of the fermented cassava peels broth when compared to the unfermented broth (Table 1) could be attributed to the ability of the fungi complex to hydrolyze starch into glucose which may ultimately have been used by the organisms as a carbon source to synthesize biomass rich in protein. The proportionate increase in the protein content of the fermented peels could also have accounted for the decrease in the carbohydrate content (35).

Table 1. Proximate analysis result of unfermented and fermented cassava peels.

\begin{tabular}{lll}
\hline Composition & Unfermented & Fermented \\
\hline Moisture content & 86.29 & 31.60 \\
Ash & 4.88 & 10.23 \\
Protein & 6.24 & 11.22. \\
Fat & 1.39 & 2.91 \\
Crude fibre & 10.88 & 8.87 \\
Cyanide & $118.86 \mathrm{ppm}$ & $20.46 \mathrm{ppm}$ \\
Starch & 56.72 & 20.09 \\
\hline
\end{tabular}

\subsection{Cyanide Content}

There was a significant decrease in the cyanide content of the cassava peels broth at the end of experiment as compared to the broth before biomass production (Table 1). This reduced value could be attributed to the fact that Aspergillus niger was capable of partially degrading the cyanogenic glycosides in the peels. This is in line with the reports of Yabaya, and Ado [2008] and Okpako [2008] [25, 38]. The reduction might also be due to the synergistic effect of loss of cyanogenic glycosides on hydrolysis by linamarase [39], metabolic activities of inherent microorganisms [27, 40], ability of the microorganisms to secrete extracellular enzymes (amylase, xylanase and linamarase), increase in cell mass and formation of a hydrolytic complex bind force to the cyanide compound.

\subsection{Biomass Production}

Biomass content peaked on the fifth day of experiment at $8.266 \mathrm{gm}$. However, the biomass decreased on daily basis until a constant weight of $1.890 \mathrm{gm}$ was obtained on the 9 th and 10th day (Table 2).

The high yield of mycelia or biomass of $A$. niger using cassava peel broth and the persistent growth of the organism might be due to the presence of nutrients in the broth. The stability of the growth could also be as a result of the presence of cellulose in the substrate. Cellulose, starch, and pectin were likely to have been broken down to glucose and other sample sugars by carbohydrate hydrolyzing enzymes such as cellulase, amylase and pectinase known to be produced by $A$. niger. [41]. The decrease in biomass production after day 5 was due to decline in the available carbon and energy sources for the metabolic processes.

The decrease in biomass reported in this work is similar to the report of Muhammad et al. who reported maximum cell biomass of $A$. niger after $120 \mathrm{~h}$ and Penicillium javanicum after $144 \mathrm{~h}$ of fermentation. The reduction in biomass production can also be attributed to non- development of hyphae as a result of the depletion of nutrients in the medium.

Table 2. Biomass production by Aspergillus niger in cassava peels broth.

\begin{tabular}{ll}
\hline Time in minutes & Weight in grams \\
\hline 1 & 1.253 \\
2 & 2.567 \\
3 & 4.792 \\
4 & 6.043 \\
5 & 8.266 \\
6 & 3.899 \\
7 & 2.067 \\
8 & 1.890 \\
9 & 1.890 \\
\hline
\end{tabular}

\subsection{Organoleptic Qualities of Cassava Peel Medium Before and After Fermentation}

The cassava peels broth was tested for smell, taste, colour, turbidity, and acidity both before and after fermentation. Considerable changes were observed on physical examination. These changes are as a result of fermentation processes. At the start of experiment, the broth was brown but as fermentation proceeded, the broth turned deep brown. The clear liquid at the start of the experiment became cloudy and highly turbid at the expiration of the fermentation. The increase in turbidity could be as a result of the accumulation of metabolic waste of the fermenting organism as well as the presence of hyphae in the medium. The taste was bitter with distinctive acidic smell (Table 3). The acidic fermentation smell agrees with the findings by Gonzalez [2007] who opined that a good fermentation smells like acid and is fragrant [43].

The reason for the change in colour of the medium could not be far from the fact that temperature during fermentation 
causes Mailard's reaction that turns cassava peel brown [43].

Table 3. Organoleptic characteristics of fermented and unfermented cassava peels broth.

\begin{tabular}{lll}
\hline Parameters & Unfermented & fermented \\
\hline Colour & Brown & Deeper brown \\
Odour & Acidic & Fermented odour \\
Viscosity & Light & light \\
pH & 4.66 & 3.62 \\
taste & Bitter and tangy & Slightly sweet \\
turbidity & Clear & turbid \\
\hline
\end{tabular}

\section{5. pH of Both Fermented and Unfermented Cassava Peels Broth}

The $\mathrm{pH}$ of the fermenting medium at the start of experiment was 4.66 but reduced to 3.62 at the end of the experiment. This is an indication of the acidic end product of the fermentation process became more acidic as A. niger breaks down the carbohydrate in the medium to produce organic acid. This is in accordance with Balagopopal and Maini [1976] who observed a decrease in $\mathrm{pH}$ during fermentation of sweet potato. [45]

$A$. niger has been reported to produce an array of extracellular enzymes required for the degradation of the major components in agricultural wastes. [46] Femi-Ola, et al., [2013], reported that $A$. niger was superior to other species of Aspergillus and Rhizopus in amylase production. [46]. Hang et al., [1975] also reported a high biomass production in their work using brewer's spent grains to cultivate fung $i$ [47]. The enzymatic activity of this organism and the rapid breakdown of the substrate may be responsible for the biomass produced by $A$. niger. Ikenebomeh and Chikwendu, [1997] reported a dry biomass of $13 \mathrm{~g} / \mathrm{L}$ of $A$. niger grown in brewery spent grain liquor [48]. Hang, et al., $\{1975]$ observed the dry biomass production of $15.60 \mathrm{~g} / \mathrm{L}$ of $A$ niger when cultivated using cassava rind basal medium [47]. Lower biomass of $9.82 \pm 0.35 \mathrm{~g} / \mathrm{L}$ was observed using cassava whey [48].

\section{Conclusion}

Cassava peels fermented with Aspergillus niger produced materials with reduced cyanide level compared the unfermented peels. Aspergillus niger can be a good candidate for the large scale production of mycelial protein using cassava peels as the substrate. Cassava peels which are regarded as having no economic value could be engineered by microorganisms to increase nutritive value, reduce cyanide content and used as feed for farm animals provided it is accepted especially since the fungi has broken down the complex molecules, especially the fibre to become highly digestible. Furthermore, the need to explore organic waste materials as alternative source of microbial growth medium is essential due to an ever increasing high cost of substrate for microbial cultivation. The potential of the moulds to utilize agrowastes as substrates could be harnessed for effective waste management. It is recommended that the study on mycelia protein production by $A$. niger using cassava peels should be conducted on a large scale.

\section{References}

[1] Bos A, and Hamelinck C (2014) Greenhouse gas impact of marginal fossil fuel use. ProjecT number: BIENL14773 2014.

[2] Sadh, P. K., Duhan, S. and Duhan, J. S. (2018). Agroindustrial wastes and their utilization using solid state fermentation: a review. Bioresources and Bioprocess. (2018) 5: 1 .

[3] Olu. Malomo, Daniels A. O., O. Olajiga, Femi- Ola T. O. Alamu A. E. (2013). The Use of Brewer'S Spent Grains in the Cultivation of Some Fungal Isolates, International Journal of Nutrition and Food Sciences. Vol. 2, No. 1, 2013, pp. 5-9. doi: 10.11648/j.ijnfs.20130201.12.

[4] Singh P. D., Prabha, R Shukla Renu · Pramod Kumar Sahu · Vivek Singh. (2018). Agrowaste bioconversion and microbial fortification have prospects for soil health, crop productivity, and eco enterprising. Vol.:(0123456789) 1-3 International Journal of Recycling of Organic Waste in Agriculture (2019) 8 (Suppl 1): S457-S472.

[5] Okudoh, V. I., Trios, T. S. Workneh, S. Schmidt and A. Cibati (2014). Venice 2014, Fifth International Symposium on Energy from Biomass and Waste.

[6] Zvidzai, C., Muzhinji, N., Chidzvondo, F., Mundembe, R. and Sithole-Niang, I. (2007). Potential commercialization of a microbial medium formulated from industrial food waste. African. Journal of Microbiology. 1 (6): 79-87.

[7] Torres JL, Selga A, Cascane M (2004). Bioactive products from by-product and wastes. Agric. Food Chemistry. 6: 128129.

[8] Aikat K, and Bhattacharyya BC (2000). Optimization of some parameters of solid fermentation of wheat bran for protease production by a local strain of Rhizopus oryzae. Acta Biotechnology. 20: 149-159.

[9] Bhumibhamon O (1978). Production of acid protease and carbohydrate degrading enzyme by Aspergillus awamori. The Journal of Agricultural Sciences. 11: 209-222.

[10] Wang, B., Sakoda, A. and Suzuki, M. (2001). Biological efficiency and nutritional value of Pleurotus ostreatus cultivated on spent beer grain. Bioresource Technology. 78: 293-300.

[11] Bartolome B, Santos M, Jimenze JJ, del Nozal MJ, Gomez cordoves C (2002). Pentoses and hydroxycinnamic acids in brewers spent grain. Journal of Cereal Sciences. 36: 51-58.

[12] Nnolim, N. E. Okoh., A. I. and Uchechukwu U. Nwodo, U. U Biotechnology Rep (Amst). 2020 Sep; 27: e00483. Published online 2020 May 29. Proteolytic bacteria isolated from agrowaste dumpsites produced keratinolytic enzyme.

[13] Carneiro, P. and Ferreira, P. (2011). The economic, environmental and strategic value of biomass. On line publication, Accessed 3rd Dec, 2020.

[14] REN. Renewable Energy Policy Network for the 21st Century. Renewables 2014 Global Status Report. 2014. http://www.ren21.net/Portals/0/documents/Resources/GSR/20 14/GSR2014_full\%20 report low\%20res.pdf 
[15] Iyayi, E. A and Losel, D. M. Protein enrichment of cassava by-products through solid state fermentation by fungi. Journal of Food Technology in Africa. 2001; 6 (4): 116-118.

[16] Iyayi, E. A, and Tewe, O. O. (1988). Effect of protein deficiency on utilization of cassava peel by growing pigs. In: Proceedings of the IITA/ILCA/University of Ibadan Workshop on the Potential Utilisation of Cassava as Livestock Feed in Africa; 14-18 November 1988. Ibadan: IITA. pp. 54-57.

[17] Ruqayyah, T. I, Jamal, P, Alam, M. Z, Mirghani, M. E, Jaswir, I, Ramli, N. (2014). Application of response surface methodology for protein enrichment of cassava peel as animal feed by the white-rot fungus Panus tigrinus M609RQY. Food Hydrocolloids.; 42 (15): 298-303.

[18] Max, B., Salgado, J. M.; Rodríguez, N; Cortés, S; Converti, A; Domínguez, J. M. (October 2010). "Biotechnological production of citric acid". Brazilian Journal of Microbiology. 41 (4): 862-875.

[19] "Inventory of GRAS Notices: Summary of all GRAS Notices". US FDA/CFSAN. 2008-10-22. Archived from the original on 11 October 2008. Retrieved 2008-10-31.

[20] Ozdal, M and E. B. Kurbanoglu (2019). Citric Acid Production by Aspergillus niger from Agro-Industrial By Product; Molasses and Chicken Feather Peptone. Waste and Biomass Valorization 10 (2): 1-10.

[21] Cordenunsi, B. R., De Menezes, W. E., Genovese, M. I. Colli, C., De Souza, G. A. and Lajolo, F. M. (2004). Chemical composition and glycemic index of Brazilian pine (Araucaria angustifolia) seeds. Journal of Agricultural and Food Chemistry, vol. 52, no. 11, p. 3412-3416.

[22] Howard. J. B., and Denton I. C. (2010). Simple method to reduce the cyanogen content of gari made from cassava. Food Chemistry. Elsevier. 123: 840-845.

[23] Adepoju O. T., Adekola Y. G., Mustapha S. O., and Ogunola S I. (2010). Effect of processing methods on nutrient retention and contribution of cassava (Manihot spp.) to nutrient intake of Nigerian consumers. African Journal of Food, Agriculture, Nutrition and Development. Elsevier 10: 2099-2111.

[24] Buckle K. A., Edwars R. A., Fleet G. H., and Wooton M. (1987). Ilmu Pangan. Translated by H. Purnomo and Adiono. Universitas Indonesia: Jakarta.

[25] Okpako, C. E. Ntui, V. O., Osuagwu. A. N. and. Obasi. F. I (2008). Proximate composition and cyanide content of cassava peels fermented with Aspergillus niger and Lactobacillus rhamnosus. Journal of Food, Agriculture and Environment Vol. 6 (2): $251-255$.

[26] AOAC, (2015). Official method or analysis. 14th edition, Association of Official Analytical Chemical Washington.

[27] Oboh, G. and Akindahunsi, A. A. (2003). Biochemical changes in cassava products (flour and garri) subjected to Saccharomyces cerevisae solid media fermentation. Food Chemistry 82 (4): 559-662.

[28] Day, C. N., and Morawicki, R. O. (2018). Effects of fermentation by yeast and amylolytic lactic acid bacteria on grain sorghum protein content and digestibility. Hindawi Journal of Food Quality, 2018, 1-8.

[29] Oboh, G. (2006). Nutrient enrichment of cassava peels using a mixed culture of Saccharomyces cerevisae and Lactobacillus spp. solid media fermentation technique. Electronic Journal of Biotechnology 9 (1): 46-49.

[30] Rainbult, M. (1998). General and microbiological aspects of solid substrate fermentation, Electronic Journal of Biotechnology [online], 15 December 1998, vol. 1, no.

[31] Antai, S. P. and Mbongo P. M. (1994). Utilization of cassava peels as substrate for crude protein formation. Plant Foods for Human Nutrition, December vol. 46, no. 4, p. 345-351.

[32] Oboh, G.; Akindahunsi, A. A. and Oshoodi, A. A (2002). Nutrient and anti-nutrient content of Aspergillus niger fermented cassava products (flour and gari). Journal of Food Composition and Analysis, 15 (5), 617-622.

[33] Obueh HO, Ikenebomeh MJ. (2014). Bioethanol production and compositional changes during fermentation of cassava processing wastes from a local cassava mill. International Journal of Current Research in Biosciences. Plant Biology, 2014, 1: 43-51.

[34] Akinfala E. O, Tewe O. O. (2004). Supplemental effects of feed additives on the utilization of whole cassava plant by growing pigs in the tropics. Livestock Research in Rural Development, 16: 86-103.

[35] Tweyongyere, R. and Katongle, I. (2002). Cyanogenic potential of cassava peels and their detoxification for utilization as livestock feed. Veterinary and Human Toxicology 44 (6): 366-389.

[36] Padjama, G, and Steinkraus, K. H. (1995). Cyanide detoxification in cassava for food and feed uses. Critical Reviews in Food Science and Nutrition 35, (4) 299-339.

[37] Aro, S. O. (2008). Improvement in the nutritive quality of cassava and its by-products through microbial fermentation. African Journal of Biotechnology Vol. 7 (25), pp. 4789-4797, 29

[38] Yabaya, A. and Ado, S (2008). Mycelial protein production by Aspergillus niger using banana peels. A Science world Journal. 3 (4) 2008 9-12.

[39] Muhammad I. R, Muhammad S. A, Sohail H. K and Abu saeed H. (2004). Production of single cell protein from rice polishings using Candida utilis. World Journal of Microbiology and Biotechnology . DOI: 10.1023/B:WIBI.0000023845.96123.dd

[40] Lubna I, Nadeem M, Baig SJ, Syed QA and. Rana F. R. (2004). Bioconversion of citrus waste into protein richbiomass by Aspergillus niger. Pakinstan Journal Biochemistry and Molecular Biology. 37: 172-176.

[41] Khan, M. Y., Dahot, M. U. and Khan, M. Y. (1992). Single cell protein production by Penicillum javanicum from pretreated rice husk. Journal. Islamic Academic. Sciences. 5, 39-43.

[42] Abdelhadi, L. O., Santin, F. J., and Gagliostro G. A. (2005). Corn fermentation of high moisture corn supplements for beef heifers grazing temperate pasture; effects on performance ruminal fermentation and in situ pasture digestion. Animal Feed Science and Technology. 118: 63-78.

[43] Gonzalez J., Farı-M armol J, Rodriguez C. A, and Martınez A (2007). Effects of ensiling on ruminal degradability and intestinal digestibility of Italian rye-grass. Animal Feed Sciences and Technology. 136: 38-50. 
[44] Ogunsuyi H. O. (2015). Assessment of sweet potato peel as a potential raw material for bioethanol fuel. International Advanced Research Journal in Science, Engineering and Technology. 2015; 2 (12). 2394-1588.

[45] Balagopopal C, Maini SB (1976). Evaluation of certain species of fungi for single cell protein and amylase production in cassava liquid medium. Journal of Root Crops. 2: 49-51.

[46] Femi-Ola, T. O, Daniels, T and O. F Olajiga (2013).
Propagation of selected fungal isolates using media formulated from brewery spent waste. Bioscience Research, 10 (2): 60-64, 2013.

[47] Hang, Y. D., Splittoesser, D. F. and Woodams, E. E. (1975). Utilization of Brewery spent grain liquor by Aspergillus niger. Applied and Environmental Microbiology. P. 879-880.

[48] Ikenebomeh, M. J, Chikwendu, A. E (1997). Aspergillus niger biomass production in cassava whey medium. Nigerian Journal of Microbiology. 11: 52-63. 1997. 